Jurnal Ners Indonesia, Vol.11 No.2, Maret 2021

\title{
RESPON PSIKOLOGIS PERAWAT SELAMA PANDEMIK COVID-19: SCOPING REVIEW
}

\author{
Muhamad Ridlo $^{1}$, Suhartini Ismail ${ }^{2 *}$, Nana Rochana ${ }^{3}$, Sarinti $^{4}$ \\ ${ }^{1}$ Mahasiswa Magister Keperawatan, Departemen Ilmu Keperawatan, Fakultas kedokteran, \\ Universitas Diponegoro, Semarang, Indonesia. \\ ${ }^{2}$ Divisi Keperawatan Gawat Darurat, Departemen Ilmu Keperawatan, Fakultas Kedokteran, \\ Universitas Diponegoro, Semarang, Indonesia. \\ ${ }^{3}$ Dosen Keperawatan Gawat Darurat dan kritis, Departemen Ilmu Keperawatan, Fakultas Kedokteran, \\ Universitas Diponegoro, Semarang, Indonesia. \\ ${ }^{4}$ Perawat Unit Perawatan Intensif, RSUD dr. Adhyatma, MPH, Semarang. \\ "Corespondence author email address: suhartini.ismail@ fk.undip.ac.id
}

\begin{abstract}
Abstrak
Penyakit Coronavirus 2019 (COVID-19) telah menyebar ke seluruh dunia dan perawat berisiko tinggi tertular hingga mengalami kematian akibat virus tersebut, yang mengakibatkan sekitar 55 perawat di Indonesia meninggal dunia. Artikel ini bertujuan untuk mendapatkan gambaran yang komprehensif terkait respon psikologis perawat selama pandemi COVID-19. Studi ini menggunakan model Arksey dan O'Malley dalam melakukan analisis. Literatur yang dilakukan analisis terdiri dari Sciencedirect, Scopus, EBSCO, ProQuest, dan SpringerLink dari Januari sampai September 2020. Identifikasi dan pilih literatur menggunakan Preferred Reporting Items for Systematic Reviews and Meta-analysis (PRISMA). Hasilnya sebanyak 13 artikel yang dilakukan analisis terdiri dari 2 artikel kualitatif dan 11 artikel kuantitatif. Artikel ini merangkum temuan tentang respon psikologis perawat selama pandemi COVID-19 meliputi: kecemasan, gejala depresi, perasaan takut, khawatir dan adanya stres akut. Selama pandemi COVID-19, perawat harus memberikan pelayanan yang optimal kepada masyarakat terkait pencegahan dan pengendalian infeksi. Hal tersebut menimbulkan respon psikologis yang terjadi pada perawat saat merawat pasien COVID-19. Respon psikologis yang didapat dari pernyataan langsung perawat menjadi sumber informasi untuk memberikan intervensi psikologis bagi perawat dalam meningkatkan kesehatan mental selama pandemi COVID-19.
\end{abstract}

Kata kunci: COVID-19, pandemik, perawat, scoping review respon psikologis,

\begin{abstract}
Coronavirus disease 2019 (COVID-19) has spread worldwide and nurses are at high risk of infection until death caused by the virus, it is about 55 nurses in Indonesia dying. The study aims to get a comprehensive discription that relates to the psychological response of nurses during the COVID-19 pandemic. This study employs the Arksey and O'Malley models for analysis. The literature was conducted by the analysis consists of Sciencedirect, Scopus, EBSCO, ProQuest, and SpringerLink from January to September 2020. Identifying and selecting literature used Preferred Reporting Items for Systematic Reviews and Meta-analysis (PRISMA). The result of 13 articles were analyzed that consisted of 2 qualitative articles and 11 quantitative articles. This article summarized the findings obtained from a description of the psychological response of nurses during the COVID19 pandemic including: anxiety, symptoms of depression, feeling of fear, worried, and acute stress. During the COVID-19 pandemic, nurses must provide optimal services to the community regarding infection prevention and control. It will lead to a psychological response that occurs in nurses while caring for COVID-19 patients. The psychological responses that have collected will be a source of information to provide psychological interventions for nurses to improve mental health during the COVID-19 pandemic.
\end{abstract}

Keyword: COVID-19, nurses, pandemic, psychological responses, scoping review 
Muhamad Ridlo, Suhartini Ismail, Nana Rochana, Sarinti, Respon Psikologis Perawat Selama Pandemik COVID-19: Scoping Review

\section{PENDAHULUAN}

Coronavirus Disease 2019 atau COVID19 merupakan penyakit infeksi virus yang terus mengalami peningkatan jumlah kasus yang terkonfirmasi di seluruh dunia. COVID-19 telah berkembang dalam penyebarannya dan mengancam kesehatan di seluruh dunia (Lau et al., 2020). World Health Organization (WHO) melaporkan kasus terkonfirmasi positif COVID-19 secara global per 31 Agustus 2020 yaitu sebanyak 24.854.140 kasus. Angka kematian pada pasien COVID-19 mencapai $838.924(29,62 \%)$ kasus. Di wilayah Asia Tenggara, negara Indonesia menduduki peringkat kedua kejadian COVID-19 terbanyak setelah negara India dengan jumlah kasus terkonfirmasi positif sebanyak 169.195 dan mengalami peningkatan yang signifikan selama setiap minggunya. Jumlah kasus baru di Indonesia setiap minggunya mencapai 17.697 kasus dengan angka kematian mencapai 667 kasus (World Health Organization, 2020).

The International Council of Nurse (ICN) meminta kepada pemerintah untuk mencatat jumlah petugas kesehatan garda depan yang terinfeksi dan meninggal akibat COVID-19. Selain itu juga untuk mengambil tindakan yang diperlukan dalam melindungi perawat dari penularan COVID-19. ICN melakukan analisis berdasarkan data dari National Nursing Associations menunjukkan bahwa per 03 juni
2020 lebih dari 230.000 petugas kesehatan telah terinfeksi COVID-19, dan lebih dari 600 perawat telah meninggal karena virus tersebut (International Council of Nurse, 2020). Sedangkan untuk negara Indonesia, Ikatan Ahli Kesehatan Masyarakat Indonesia (IAKMI) melaporkan per 1 Agustus 2020 angka kematian tenaga kesehatan mencapai 153 kasus. Dari jumlah angka kematian tersebut, tenaga kesehatan khususnya perawat mencapai 55 kasus kematian (Cable News Network Indonesia, 2020).

Pandemi COVID-19 yang sudah menyebar ke seluruh Indonesia, membuat pemerintah mengambil tindakan aktif dan efektif dalam membantu pengendalian penyebaran COVID-19 yang dilakukan oleh petugas kesehatan (Z. Li et al., 2020). Petugas kesehatan sebagai garda depan antara lain yaitu dokter, perawat, petugas radiologi, laboratorium dan staf rumah sakit dalam pengontrolan infeksi (Cai et al., 2020; Mohindra, R, Suri, Bhalla, \& Singh, 2020). Perawat dalam tugasnya memberikan asuhan keperawatan kepada pasien berisiko terpapar (COVID-19). Selama pemberian asuhan keperawatan, perawat terlibat dalam proses diagnosis, pencegahan, pengontrolan dan perawatan pasien secara langsung, sehingga memiliki tingkat risiko tertular yang tinggi (Sun et al., 2020). Risiko penularan yang tinggi pada 
Jurnal Ners Indonesia, Vol.11 No.2, Maret 2021

perawat disebabkan kerena perawat selalu kontak dengan pasien selama proses perawatan dan jam bekerja lebih lama dari biasanya (Mohindra et al., 2020). Hal ini membuat, perawat sebagai petugas kesehatan garis depan mengalami beban psikologis dalam merawat pasien COVID-19 (Lai et al., 2020). Beban psikologis yang dialami akan menimbulkan suatu respon yang disebut dengan respon psikologis.

Respon psikologi yang timbul dan merugikan diantaranya yaitu adanya perasaan ketakutan akan penularan dan penyebaran virus ke keluarga, teman dan antar teman sejawat lainnya (Xiang et al., 2020). Perawat atau petugas kesehatan juga mengalami stres, kecemasan, kemarahan, penyangkalan, traumatisasi dan gejala depresi selama pandemi COVID-19 (Asmundson \& Taylor, 2020; Z. Li et al., 2020). Selain itu, adanya stigma yang diberikan masyarakat kepada perawat dalam merawat pasien COVID-19. Stigma yang yang dialami perawat seperti dihindari teman yang lain, tidak adanya dukungan, harus tinggal di asrama atau ruangan isolasi, dan membatasi kontak dengan lingkungan sekitar (Rana, Mukhtar, \& Mukhtar, 2020).

Hasil penelitian yang dilakukan oleh Sun et al., (2020) menunjukkan perawat yang merawat pasien COVID-19 mengalami adanya stres akibat dari ketakutan berada diruang perawatan dengan tekanan negatif dan merasakan kecemasan akan menularkan virus tersebut keanggota keluarga atau dilingkungan sekitarnya. Selain itu, penelitian yang dilakukan oleh Haozheng menunjukkan bahwa stres yang terjadi pada petugas garda depan karena terkait masalah pada keamanan pribadi selama bekerja dan khawatir akan menularkan virus keanggota keluarga. Stres yang dialami perawat tambah berat saat melihat pasien yang dirawat dalam kondisi meninggal dunia. Selain itu, kecemasan juga dialami karena kurangnya alat perlindungan diri dalam bekerja dan kelelahan akibat meningkatnya jumlah jam bekerja (Cai et al., 2020).

Beberapa penelitian sebelumnya menunjukkan bahwa respon psikologis yang dialami perawat berbeda-beda selama pandemik COVID-19 (Asmundson \& Taylor, 2020; Cai et al., 2020; Z. Li et al., 2020; Rana et al., 2020; Sun et al., 2020). Oleh karena itu, eksplorasi mendalam tentang respon psikologis perawat baik yang menangani pasien COVID-19 secara langsung ataupun tidak, sangat perlu untuk dilakukan melalui scoping review. Scoping review yang dibuat ini bertujuan untuk mendapatkan gambaran secara menyeluruh terkait dengan respon psikologis perawat selama pandemik COVID-19. 
Muhamad Ridlo, Suhartini Ismail, Nana Rochana, Sarinti, Respon Psikologis Perawat Selama Pandemik COVID-19: Scoping Review

\section{METODE PENELITIAN}

\section{Desain studi}

Artikel ini menggunakan kerangka metodologi oleh Arksey dan O’Malley dalam melakukan scoping review. Metode yang digunakan ini ada lima langkah yang harus dilakukan antara lain mengidentifikasi pertanyaan penelitian secara jelas dan obyektif; mengidentifikasi artikel yang relevan; pilihan literatur terkait dari artikel dan ekstrasi data; pengorganisasisan, meringkas, dan menganalisis; melaporkan hasil data (Arksey \& O’Malley, 2005). Pertanyaan pada artikel ini yaitu "Apa saja gambaran komprehensif dari respon psikologis perawat selama pandemic COVID-19?”.

\section{Kriteria kelayakan}

Artikel yang digunakan dalam pembuatan scoping review ini terkait psikologis yang dialami perawat selama pandemic COVID-19. Literatur yang digunakan menggunakan bahasa Inggris. Partisipan dalam artikel yang di review yaitu petugas kesehatan garda depan dalam melawan COVID-19 khususnya perawat. artikel yang tidak menggunakan bahasa Inggris, report, editorial dikecualikan.

\section{Strategi pencarian literatur}

Pencarian literature terkait, artikel ini menggunakan data based dari Sciencedirect, Scopus, EBSCO, ProQuest, dan SpringerLink.
Artikel yang relevan dengan topik pada bulan Januari sampai September tahun 2020. Dalam pencarian literatur dengan menggunakan Booleon operators “OR/AND”. Kata kunci yang digunakan dalam pencarian: ("COVID-19” AND "Nurse" AND "Psychological" OR “Anxiety” OR “Stress" OR “Stigmatization”).

\section{Identifikasi dan pemilihan literatur}

Dalam melakukan scoping review ini pencarian literatur secara independen melalui databased yang sudah terpercaya. Artikel yang sudah didapatkan dilakukan analisis, perbedaan, dan duplikasi. Pada gambar 1 menjelaskan terkait proses mencari dan memilih artikel sebagai literatur dengan menggunakan Preferred Reporting Items for Systematic Reviews and Meta-analysis for Scoping Review (PRISMA-SR) (Moher et al., 2009).

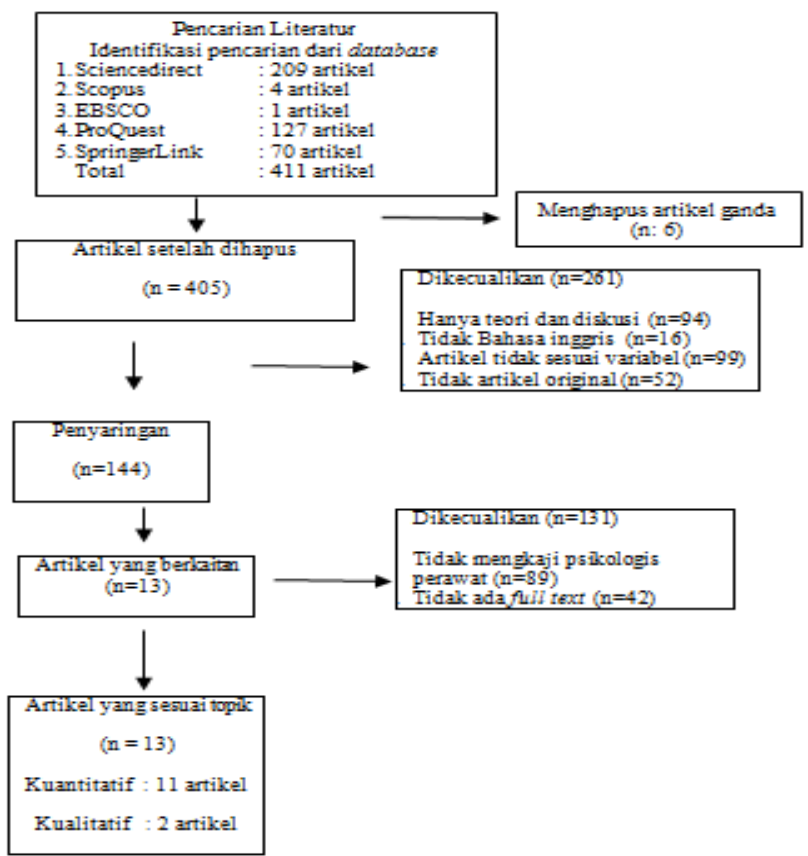

Figure 1. PRISMA flow diagram of studies search. 
Ekstraksi data dari literatur yang dipilih

Artikel yang sudah didapatkan dilakukan

ekstraksi data dalam bentuk matrik di Microsoft

word. Domain yang digunakan dalam ekstraksi data antara lain nama peneliti, tahun, negara, judul artikel, desin, responden atau partisipan, dan hasil temuan lihat pada Tabel 1.

\section{Tabel 1}

Matrik analisis pada literature

\begin{tabular}{lll}
\hline No. $\begin{array}{c}\text { Penulis, } \\
\text { Tahun, } \\
\text { Negara }\end{array}$ & \multicolumn{1}{c}{ Judul } \\
1. $\begin{array}{l}\text { (Shechter et } \\
\text { al., 2020) } \\
\text { USA }\end{array}$ & $\begin{array}{l}\text { Psychological distress, coping } \\
\text { behaviors, and preferences for } \\
\text { support among New York } \\
\text { healthcare workers during the } \\
\text { COVID-19 pandemic. }\end{array}$ \\
2. (Juan et al., & $\begin{array}{l}\text { Psychological distress } \\
\text { surveillance and related impact } \\
\text { 2020) } \\
\text { Chinalysis } \\
\text { of hospital staff during the } \\
\text { COVID-19 epidemic in } \\
\text { Chongqing, } \\
\text { China. }\end{array}$
\end{tabular}

3. (Temsah et The psychological impact of al., 2020) COVID-19 pandemic on health Arabia

4. (Lee et al., Psychological distress during 2020) the COVID-19 pandemic Singapore

5. (Lu, Wang, Psychological status of medical Lin, \& $\mathrm{Li}$, workforce during the COVID-19 2020)

China pandemic:

6. (Shen, Zou, Zhong, Yan, \& Li, 2020) China

7. (H. Wang et The psychological impact of al., 2020) China

\section{Desain penelitian dan sampel}

Hasil temuan care Workers in a MERS-CoV endemic country. amongs Anaesthesiologists and nurses. A cross-sectional study.

Cross-sectional study dengan metode web survey

Terdapat 657 responden, untuk tenaga perawatnya ada 313 .

Cross-sectional study dengan metode survey Terdapat 456 responden, untuk tenaga perawatnya ada 258 .

\section{Quantitative study}

Terdapat 811 respon, untuk tenaga perawatnya ada 363 .

Cross-sectional study dengan observasi Terdapat 279 respon, untuk tenaga perawat ada 158 .

Cross-sectional study dengan metode kuesioner online Terdapat $\quad 2.042$ responden antara dokter dan perawat.

Psychological stress of ICU Qualitative study

nurses in the

time of COVID-19
COVID-19

pandemic on medical staff in Guangdong,

China: a cross-sectional study.
Quantitative dengan metode group WeChat

Terdapat

1045 responden, untuk tenaga perawat ada 773 .
Adanya gangguan psikologis pada perawat seperti kecemasan $(33 \%)$, stress akut (57\%), dan gejala depresi (48\%).

Adanya gejala tekanan psikologis pada perawat termasuk $(33,3 \%)$, kecemasan $(31,6 \%)$, dan depresi $(29,6 \%)$.

Adanya gangguan psikologis pada perawat seperti kecemasan dan khawatir. Untuk tingkat kecemasan yang dialami terdapat: kecemasan ringan, kecemasan sedang, kecemasan tinggi, kecemasan sangat tinggi.

Adanya tekanan psikologis pada perawat seperti depresi $(50,4 \%)$ dan kecemasan (44,6\%).

Adanya gangguan psikologis yang dialami perawat seperti ketakutan, kecemasan dan gejala depresi.

Adanya masalah psikologis yang dialami perawat seperti kecemasan, khawatir akan terinfeksi dan menularkan ke keluarga, kelelahan jangka panjang, depresi.

Adanya respon psikologis yang terjadi pada perawat selama pandemik COVID-19 seperti kecemasan $(55,4 \%)$ dan depresi (43,6\%). 
Muhamad Ridlo, Suhartini Ismail, Nana Rochana, Sarinti, Respon Psikologis Perawat Selama Pandemik COVID-19: Scoping Review

\begin{tabular}{|c|c|c|c|c|}
\hline No. & $\begin{array}{l}\text { Penulis, } \\
\text { Tahun, } \\
\text { Negara }\end{array}$ & Judul & $\begin{array}{r}\text { Desain peneliti } \\
\text { sampel }\end{array}$ & Ha \\
\hline 8. & $\begin{array}{l}\text { (Sun et al., } \\
2020) \\
\text { China }\end{array}$ & $\begin{array}{l}\text { A qualitative study on the } \\
\text { psychological experience of } \\
\text { caregivers of COVID-19 } \\
\text { patients. }\end{array}$ & $\begin{array}{l}\text { Qualitative study } \\
\text { Terdapat } 20 \text { partisipan } \\
\text { perawat. }\end{array}$ & $\begin{array}{l}\text { Adanya pengalaman psikologis } \\
\text { pada perawat seperti ketakutan } \\
\text { akan terinfeksi, khawatir akan } \\
\text { menularkan keanggota keluarga, } \\
\text { dan kecemasan. }\end{array}$ \\
\hline 9. & $\begin{array}{l}\text { (Cai et al., } \\
\text { 2020) } \\
\text { China }\end{array}$ & $\begin{array}{l}\text { Psychological Impact and } \\
\text { Coping Strategies of } \\
\text { Coronavirus Disease 2019 } \\
\text { (COVID- 19) January and } \\
\text { March 2020 During the } \\
\text { Outbreak of Frontline Medical } \\
\text { Staff in Hunan Between in } \\
\text { Hubei, China }\end{array}$ & $\begin{array}{l}\text { Cross-sectional study } \\
\text { Terdapat } 534 \text { responden, } \\
\text { untuk tenaga perawat } \\
\text { ada } 248 .\end{array}$ & $\begin{array}{l}\text { Adanya dampak psikologis yang } \\
\text { dialami seperti stress, kecemasan } \\
\text { dan kekhawatiran berlebih. }\end{array}$ \\
\hline 10. & $\begin{array}{l}\text { (Hu et al., } \\
2020) \\
\text { China }\end{array}$ & $\begin{array}{l}\text { Frontline nurses' burnout, } \\
\text { anxiety, depression, and fear } \\
\text { statuses and } \\
\text { their associated factors during } \\
\text { the COVID-19 outbreak in } \\
\text { Wuhan, China: } \\
\text { A large-scale cross-sectional } \\
\text { study }\end{array}$ & $\begin{array}{l}\text { A large-scale cross- } \\
\text { sectional, descriptive, } \\
\text { correlational study } \\
\text { Terdapatr semuanya } \\
\text { responden } 2014 \\
\text { tenaga perawat. }\end{array}$ & $\begin{array}{l}\text { Adanya masalah psikologis pada } \\
\text { perawat selama merawat pasien } \\
\text { COVID-19 seperti kcemasan, } \\
\text { depresi dan ketakutan karena } \\
\text { COVID-19. }\end{array}$ \\
\hline 11. & $\begin{array}{l}\text { (Aksoy \& } \\
\text { Koçak, 2020) } \\
\text { Turkey }\end{array}$ & $\begin{array}{l}\text { Psychological effects of nurses } \\
\text { and midwives due to COVID-19 } \\
\text { outbreak: The case of Turkey }\end{array}$ & $\begin{array}{l}\text { Quantitative dengan } \\
\text { pendekatan descriptive } \\
\text { Terdapat } 785 \text { responden, } \\
\text { untuk tenaga perawat } \\
\text { ada } 431 .\end{array}$ & $\begin{array}{l}\text { Adanya dampak psikologis yang } \\
\text { dialami perawat selama pandemik } \\
\text { COVID-19 seperti kecemasan } \\
(36,3 \%) \text {, ketidaknyamanan } \\
(31,3 \%) \text { dan ketakutan }(19,4 \%) \text {. }\end{array}$ \\
\hline 12. & $\begin{array}{l}\text { (Elhadi et al., } \\
\text { 2020) } \\
\text { Libya }\end{array}$ & $\begin{array}{l}\text { Psychological status of } \\
\text { healthcare workers during the } \\
\text { civil war and COVID19 } \\
\text { pandemic: A cross-sectional } \\
\text { study }\end{array}$ & $\begin{array}{l}\text { Cross-sectional study } \\
\text { Terdapat } 745 \text { responden, } \\
\text { petugas kesehatan garda } \\
\text { depan. }\end{array}$ & $\begin{array}{l}\text { Adanya masalah psikologis pada } \\
\text { perawat seperti gejala depresi, } \\
\text { kecemasan dan stigma yang } \\
\text { dialami selama merawat pasien } \\
\text { COVID-19. }\end{array}$ \\
\hline 13. & $\begin{array}{l}\text { (Hong et al., } \\
\text { 2020) } \\
\text { China }\end{array}$ & $\begin{array}{l}\text { Immediate psychological impact } \\
\text { on nurses working } \\
\text { at } 42 \text { government-designated } \\
\text { hospitals during } \\
\text { COVID-19 outbreak in China: } \\
\text { A cross-sectional study }\end{array}$ & $\begin{array}{l}\text { Cross-sectional study } \\
\text { Terdapat } \quad 4.692 \\
\text { responden semuanya } \\
\text { tenaga perawat. }\end{array}$ & $\begin{array}{l}\text { Adanya dampak psikologis yang } \\
\text { terjadi pada perawat seperti gejala } \\
\text { depresi sampai ingin melakukan } \\
\text { bunuh diri, kecemasan, dan } \\
\text { stigmatisasi akibat diskriminasi. }\end{array}$ \\
\hline
\end{tabular}

artikel. Dari 405 artikel, 261 artikel yang

\section{HASIL PENELITIAN}

Karakteristik studi

Sebanyak 411 artikel yang didapatkan sebagai literatur dari Sciencedirect (209 artikel), Scopus (4 artikel), EBSCO (1 artikel), ProQuest (127 artikel), SpringerLink (70 artikel). Ada 6 artikel yang sama pada data based untuk dikecualikan dan tersisa 405 dikecualikan karena hanya berupa teori dan diskusi, tidak bahasa Inggris, artikel tidak berkaitan dengan topik dan bukan original artikel. Hasil penyaringan artikel didapatkan 144 dan dilakukan pengecualian terkait penjelasan psikologis perawat dan artikel lengkap didapatkan 13 artikel terkait. Dari 13 artikel yang akan dilakukan analisis, 2 artikel 
dengan desain penelitian kualitatif sedangkan 11 artikel dengan desain kuantitatif. Diantara 11 artikel yang akan dilakukan analisis semuanya membahas tentang psikologis perawat selama pandemik COVID-19. Populasi pada artikel yang dilakukan analisis terdiri dari dokter, bidan dan terbanyak perawat. Penelitian yang dilakukan terdapat 1 dari negara Amerika, 1 negara Arabia, 1 negara Singapore, 1 negara Turkey, 1 negara Libya dan ada 8 dari negara China.

Artikel ini merangkum tema yang didapatkan dari respon psikologis perawat yang timbul selama pandemik COVID-19 antara lain: kecemasan, gejala depresi, perasaan takut, khawatir dan adanya stres akut.

Tema 1: Kecemasan

Literatur yang didapatkan ada tiga belas artikel menemukan adanya perasaan kecemasan yang dirasakan perawat selama pandemik COVID-19. Penelitian yang sudah ada didapatkan angka prevalensi kecemasan yang dirasakan perawat pada rentang 9,4\% sampai 54,5\% (Aksoy \& Koçak, 2020; Elhadi et al., 2020; Hong et al., 2020; Hu et al., 2020; Juan et al., 2020; Lee et al., 2020; Shechter et al., 2020; H. Wang et al., 2020). Kecemasan yang dirasakan perawat lebih tinggi dari pada tenaga kesehatan yang lain (40\% vs $15 \%(\mathrm{p}=0,001))$ (Cai et al., 2020; Shechter et al., 2020). Kecemasan pada perawat wanita lebih tinggi dibandingkan dengan perawat laki-laki selama merawat pasien COVID-19 (Juan et al., 2020). Respon psikologis kecemasan pada perawat dikategorikan menjadi tiga tingkatan antara lain: tidak ada kecemasan (skor 0-6), kecemasan ringan sampai dengan sedang (skor 7-13) dan kecemasan berat (skor $\geq 14$ ) (Hu et al., 2020; Lu et al., 2020). Tingkat kecemasan perawat selama pandemik COVID-19 secara signifikasi lebih tinggi daripada tingkat kecemasan dari Middle East Respiratory Syndrome-Coronavirus (MERS-CoV) atau flu yang lain (Temsah et al., 2020).

Faktor yang berhubungan terhadap perasaan kecemasan pada perawat berkaitan dengan tidak ingin bekerja atau keinginan untuk mengundurkan diri dari merawat pasien COVID-19 (OR, 3.622; 95\% CI, 1.882-6.973; $P<0,001)$, takut untuk pulang ke rumah karena akan menularkan ke anggota keluarga (OR, 1.803; 95\% CI, 1.069-3.039; $P=0,027)$, dan keselamatan terhadap dirinya sendiri yang rendah (Cai et al., 2020; Juan et al., 2020; Temsah et al., 2020). Selain itu, perasaan kecemasan muncul berkiatan tentang pekerjaan yang beda dengan biasanya dan kurangnya pengalaman kerja di bidang infeksi khususnya diruang isolasi COVID-19 (Shen et al., 2020). Kecemasan yang dialami juga karena adanya beberapa penyakit penyerta pada perawat, keterlibatan langsung dalam proses perawatan 
Muhamad Ridlo, Suhartini Ismail, Nana Rochana, Sarinti, Respon Psikologis Perawat Selama Pandemik COVID-19: Scoping Review

pasien COVID-19, dan melakukan perintah karantina atau isolasi mandiri (Lee et al., 2020).

Alat atau instrumen yang digunakan dalam pengukuran kecemasan dengan SelfRating Anxiety Scale (SAS) (Hu et al., 2020), Hospital Anxiety and Depression Scale-Anxiety (HADS-A) (Lee et al., 2020; H. Wang et al., 2020), State Trait Anxiety Inventory (STAI) (Aksoy \& Koçak, 2020), Generalized Anxiety Disorder (GAD) (Juan et al., 2020; Shechter et al., 2020; Temsah et al., 2020), Hamilton Anxiety Scale (HAMA) (Lu et al., 2020).

\section{Tema 2: Gejala Depresi}

Ada sembilan artikel yang didapatkan membahas terkait gejala depresi pada perawat salama pandemik COVID-19. Petugas kesehatan sebagai garda depan yang terlibat dalam perawatan pasien COVID-19 secara langsung berpotensi lebih rentan terhadap gangguan psikologis salah satunya gejala depresi (Lai et al., 2020; Lu et al., 2020). Prevalensi angka kejadian gejala depresi pada perawat terdapat pada rentang $8,1 \%$ sampai 56,3\% (Elhadi et al., 2020; Hong et al., 2020; $\mathrm{Hu}$ et al., 2020; Juan et al., 2020; Lee et al., 2020; Shechter et al., 2020; H. Wang et al., 2020). Hasil penelitian (Lee et al., 2020), menunjukkan terdapat 270 petugas garda depan, ada $155(57,4 \%)$ tenaga perawat dengan sebagian besar berjenis kelamin perempuan
$(70,7 \%)$ dan terlibat langsung dalam menangani pasien COVID-19 mengalami gejala depresi. Gejala depresi pada perawat lebih banyak terjadi dari pada dokter dengan nilai signifikasi (53\% vs 38\%, $P=0,004$ ) (Shechter et al., 2020). Perawat yang mengalami adanya gejala depresi dikategorikan menjadi tiga antara lain: normal, ringan, sedang sampai pada gejala depresi berat(Hu et al., 2020; Juan et al., 2020; H. Wang et al., 2020). Gejala depresi dapat dinilai mulai dari ketidakseimbangan emosional, fisiologis, psikomotor, dan psikologisnya $(\mathrm{Hu}$ et al., 2020).

Faktor yang berhubungan dengan adanya gejala depresi seperti adanya stigmatisasi dan penolakan dari lingkungan sekitar karena bekerja dirumah sakit (OR, 2.297; 95\% CI, 1.138-4.637; $P=0,020)$, tidak ingin bekerja atau ingin mengundurkan diri dari pekerjaan (OR, 3.134; 95\% CI, 1.635-6.006; $P=0,001$ ) dan adanya ketidakpastian terkait frekuensi modifikasi prosedur dan pengendalian infeksi (OR, 1.645; 95\% CI, 1.075-2.517; $P=0,022)$ (Juan et al., 2020). Stigma yang terjadi pada perawat berkaitan dengan pekerjaanya yang selalu kontak dengan pasien COVID-19 dan harus melakukan isolasi mandiri atau menyendiri (Elhadi et al., 2020). Perawat juga mengalami adanya diskriminasi berkaitan dengan stress pekerjaan seperti jam kerja yang lama, harus menggunakan alat perlindungan 
diri yang ketat, dan pengalaman bekerja diruang COVID-19. Selain itu, diskriminasi juga terjadi karena tidak cukupnya dukungan dari keluarga dan teman sejawat dalam bekerja merawat pasien COVID-19 (Hong et al., 2020). Hal tersebut terjadi karena perawat memiliki resiko tinggi untuk menularkan keorang lain maupun lingkungan sekitarnya.

Perawat sebagai petugas kesehatan garda depan dalam menjalankan tugasnya juga mengalami adanya perasaan frustasi karena harus bekerja diruang isolasi, khawatir akan terinfeksi, kekurangan alat perlindungan diri selama bekerja, pandemik yang tidak akan pernah bisa dikendalikan, hasil pekerjaan yang tidak memuaskan dalam merawat pasaien COVID-19, dan merasa kesepian karena diisolasi dari anggota keluarga atau sekitarnya (Lu et al., 2020). Gejala depresi yang terjadi pada perawat sampai memiliki pemikiran untuk melakukan bunuh diri dan menyakiti diri sendiri (Hong et al., 2020).

Alat atau instrument yang digunakan dalam pengukuran gejala depresi dengan SelfRating Depression Scale (SDS) (Hu et al., 2020), Hospital Anxiety and Depression ScaleDepression (HADS-D) (H. Wang et al., 2020), Hamilton Depression Scale (HAMD) (Lu et al., 2020), dan Patient Health Questionnaire-9 (PHQ-9) (Hong et al., 2020).
Tema 3: Perasaan takut

Ada empat artikel yang ditemukan membahas perasaan takut pada perawat selama pnademik COVID-19. Prevalensi angka kejadian perasaan takut perawat pada rentang 26,7\% sampai 36,2\% (Hu et al., 2020; Lu et al., 2020). Hasil penelitian menunjukkan perawat melaporkan adanya perasaan ketakutan yang dialami selama pandemik COVID-19 dikategorikan menjadi sedang $(n=564,28 \%)$ dan tinggi ( $n=1273,36,2 \%)$ (Hu et al., 2020). Perasaan takut terjadi akibat adanya peningkatan kejadian COVID-19, beban kerja yang dilakukan perawat juga meningkat secara proporsional dengan 1,5 sampai 2 kali jam kerja normal. Perawat juga diharuskan menggunakan alat perlindungan diri sesuai dengan protokol yang mengakibatkan kelelahan dan ketidaknyamanan. Hal tersebut menimbulkan perasaan ketakutan yang dialami perawat selama pandemik COVID-19. Ketakutan muncul ketika memasuki bangsal dengan tekanan negatif untuk pertama kali (Sun et al., 2020). Selain itu, Ketakutan yang dialami berkaitan dengan adanya infeksi maupun kematian anggota keluarga atau pasien serta adanya penyebaran nosokomial kepada orang sekitar selama pandemik COVID-19 (Hu et al., 2020).

Alat atau instrumen yang digunakan dalam mengukur ketakutan pada perawat 
Muhamad Ridlo, Suhartini Ismail, Nana Rochana, Sarinti, Respon Psikologis Perawat Selama Pandemik COVID-19: Scoping Review

menggunakan Intolerance of Uncertainty

Scale-12 (IUS-12) (Aksoy \& Koçak, 2020),

Fear Scale for Healthcare Profesionals (FSHPs) (Hu et al., 2020), The Numeric Rating Scale (NRS) yang sudah dilakukan uji reliabilitas validitas dan sensitivitas (Lu et al., 2020).

Tema 4: Khawatir

Ada empat artikel yang menemukan adanya respon psikologis khawatir pada perawat. Prevalensi angka kejadian perasaan khawatir pada perawat yaitu 41,41\% (Temsah et al., 2020). Perawat dalam menjalankan tugas melawan COVID-19 selalu merasa khawatir apa yang akan dilakukan saat kondisi pasien semakin menurun atau memburuk (Sun et al., 2020). Perasaan khawatir juga dirasakan terkait resiko terinfeksi saat merawat pasien COVID19 dan akan menularkan pada anggota keluarga (Shen et al., 2020; Sun et al., 2020). Selain itu, perawat sebagai petugas garda depan mengalami adanya perasaan kekhawatiran yang disebabkan karena harus mengikuti perintah isolasi diri dan mengetahui seseorang yang didagnosis dengan COVID-19 (Lee et al., 2020). Hasil penelitian (Shechter et al., 2020) menunjukkan bahwa $74 \%$ perawat mengalami kekhawatiran terkait penularan COVID-19 ke keluarga dan sekitarnya, harus menjaga jarak sosial dengan lingkungan sekitar, ketidakpastian tentang status COVID-19 teman sejawat, kurangnya alat perlindungan diri (APD), dan kurangnya pedoman nasional terkait pengobatan COVID-19.

Alat atau instrumen yang digunakan dalam mengukur kekhawatiran dengan kuesioner yang sudah dilakukan validitas dari pengembangan instrumen berdasarkan konsensus kelompok multidisiplin dengan skala likert 5 poin (Shechter et al., 2020), worry rating scale 1-5 (Temsah et al., 2020).

Tema 5: Stres akut

Ada dua artikel yang ditemukan membahas perawat selama pandemik COVID19 mengalami adanya stress akut. Prevalensi angka kejadian perawat yang mengalami stres akut sekitar 57 \% (Shechter et al., 2020). Stres akut yang dialami perawat terkait masalah keamanan pribadi, kekhawatiran akan menularkan virus keanggota keluarga dan kematian pasien yang dirawat. Selain itu juga adanya rasa kelelahan karena peningkatan jumlah jam bekerja, kurangnya alat perlindungan diri selama merawat pasien COVID-19 dan merasa tidak tenang saat berada diruang isolasi (Cai et al., 2020). Dari aspek sosial stres yang terjadi karena adanya kebiasaan tidak bertemu dengan teman atau keluarga dan tidak pergi kemana-mana selain ke tempat kerja ataupun belanja. Hal tersebut 
menyebabkan perawat merasa tidak nyaman selama pandemik COVID-19 (Aksoy \& Koçak, 2020).

Alat atau instrument yang digunakan dalam mengukur tingkat stres dengan menggunakan the 4-Item Primary Care Posttraumatic Stress Disorder (PC-PTSD) (Shechter et al., 2020) dan 14 questions to identify factors that might reduce their stress $(0=$ never $; 1=$ sometimes; 2=often; 3=always $)$ (Cai et al., 2020).

\section{PEMBAHASAN}

Scoping review ini mengumpulkan gambaran terkait respon psikologis perawat selama pandemik COVID-19. Respon psikologis yang didapatkan dalam menganalisis 13 artikel antara lain: kecemasan, gejala depresi, perasaan takut, khawatir dan stres akut.

Respon psikologis yang terjadi pada perawat mengalami adanya perasaan kecemasan. Perasan kecemasan lebih banyak terjadi pada perawat dengan jenis kelamin perempuan. Dari hasil studi (Lai et al., 2020) menunjukkan kecemasan yang lebih parah umumnya terlihat pada perawat wanita yang bekerja di Wuhan (pusat penyebaran COVID19 di China). Wanita lebih rentan mengalami kecemasan karena adanya hormon estradiol dan progesteron yang memiliki peran penting dalam keseimbangan gangguan emosi (Li \& Graham,
2017). Selain itu, kecemasan yang terjadi disaat pandemik COVID-19 lebih tinggi dari pada kejadian MERS-CoV. Hal tersebut terjadi akibat akan menularkan keanggota keluarga, kurangnya pengalaman bekerja diruang isolasi dan keterlibatan langsung dalam proses perawatan pasien COVID-19 (Rana et al., 2020). Hasil penelitian Barry menunjukkan bahwa tindakan pencegahan dan pengendalian infeksi COVID-19, petugas kesehatan memiliki tingkat kecemasan yang jauh lebih tinggi dibandingkan dengan MERS-CoV atau jenis penyakit yang lain. Kecemasan disebabkan karena COVID-19 jenis virus baru yang muncul dengan penularan yang tidak pasti, penyebarannya yang sangat cepat dan informasi yang ada masih belum jelas (Barry, Al Amri, \& Memish, 2020). Sehingga perawat mengalami kecemasan yang berlebih dan menimbulkan adanya gejala depresi.

Gejala depresi muncul karena takut akan menularkan virus keanggota keluarga dan ketidakmampuan saat menghadapi pasien dengan kondisi kritis. Kondisi ini membuat, perawat mengalami rintangan yang besar dalam menjalankan tugasnya. Sehingga, perawat merasa tidak mampu dalam menjalankan tugasnya untuk memberikan pelayanan ke pasien (Y. Liu, Zhang, Hennessy, \& Zhao, 2019). Disaat pandemik ini, perawat bersusah payah dalam memberikan pelayanan untuk 
Muhamad Ridlo, Suhartini Ismail, Nana Rochana, Sarinti, Respon Psikologis Perawat Selama Pandemik COVID-19: Scoping Review

berjuang melawan COVID-19 (C. Wang et al., 2020; Xiao, 2020). Hasil penelitian menunjukkan gejala depresi pada perawat selama pandemik COVID-19 lebih tinggi tiga kali lipat dari pada petugas kesehatan yang lain di negara Singapora dan Italia (Rossi et al., 2020; Tan et al., 2020). Gejala depresi juga terjadi akibat adanya stigmatisasi yang dibuat oleh masyarakat kepada petugas kesehatan sebagai garda depan. Stigma tersebut muncul karena ada anggapan bahwa perawat akan menularkan infeksi kepada masyarakat sekitar (Mohindra et al., 2020).

Petugas kesehatan khususnya perawat yang merawat pasien COVID-19 dirumah sakit memiliki resiko tinggi terinfeksi. Hal ini, membuat perawat dalam menjalankan tugasnya memilik masalah kesehatan mental salah satunya perasaan ketakutan. Ketakutan terjadi karena berkaitan dengan penularan dan penyebaran ke anggota keluarga, teman sejawat atau kolega lainnya serta pada masyarakat sekitar. Selain itu, adanya peralatan perlindungan diri yang kurang memadai untuk keselamatan diri dari penularan, isolasi, kelelahan dan kurangnya kontak dengan anggota keluarga (Rana et al., 2020). Hasil penelitian menunjukkan bahwa petugas kesehatan mengalami ketakutan karena bekerja di ruang berisiko tinggi seperti unit Severe Acut Respiratory Syndrome (SARS), memiliki anggota keluarga atau teman sejawat yang terinfeksi COVID-19, dan memiliki pengalaman ketakutan sebelumnya jauh lebih besar dari pada yang tidak memiliki pengalaman ketakutan (Xiang et al., 2020). Selain ketukan yang dirasakan, perawat juga merasakan adanya perasaan kekhawatiran selama merawat pasien COVID-19.

Perasaan khawatir timbul karena adanya peningkatan jumlah pasien yang terkonfirmasi positif dan meningkatnya jumlah provinsi maupun negara yang terkena dampak COVID19. Pandemik ini diperburuk dengan adanya informasi maupun laporan berita yang salah dan menyebabkan kesalahpahaman terkait dari informasi kesehatan yang diperoleh. Sehingga, petugas kesehatan maupun masyarakat mengalami perasaan kekhawatiran yang berlebih selama pandemik COVID-19 (Bao, Sun, Meng, Shi, \& Lu, 2020). Selain itu, perasaan khawatir terjadi apabila perawat akan pulang kerumah karena beranggapan sebagai sumber infeksi bagi anggota keluarga maupun masyarakat sekitar.(Mohindra et al., 2020) Perawat juga merasa khawatir mengenai kemampuan dalam mengendalikan penularan, penyebaran dan merawat pasien COVID-19 (Q. Liu et al., 2020). Perawat yang mengalami kekhawatiran berlebih selama pandemik COVID-19 akan berisiko mengalami stres . 
Petugas kesehatan khususnya perawat yang paling rentang mengalami stres. Stres yag dialami perawat berkaitan dengan tanggung jawab dalam memberikan pelayanan ke pasien. Selain itu, perawat juga menghabiskan lebih banyak waktu untuk memberikan perawatan pasien secara langsung. Selama adanya pandemik COVID-19, perawat memiliki tanggungjawab yang lebih besar dibandimgkan sebelum adanya COVID-19. Hal tersebut meningkatkan kemungkinan terjadinya stressor yang tinggi karena harus memberikan dukungan sosial langsung atau dukungan emosional untuk pasien sebagai pengganti keluarga pasien yang tidak diperbolehkan masuk rumah sakit karena masalah transmisi atau penularan. Meskipun gejala seperti PTSD ini normal terjadi selama peristiwa traumatis, diharapkan gejala tersebut bisa berkurang saat skrining positif untuk stres akut (Manser et al., 2018). Dari beberapa respon psikologis yang terjadi pada perawat maka perlu adanya upaya untuk menanganinya.

Upaya yang dilakukan dalam menangani masalah psikologis petugas kesehatan khususnya perawat perlu adanya intervensi psikologis (Jiang et al., 2020). Intervensi psikologis yang dilakukan dalam bentuk tim hotline bantuan psikologis. Tim yang dibentuk ini bertugas memberikan bimbingan dan pengawasan kepada petugas kesehatan.
Langkah-langkah intervensi yang dilakukan pertama rumah sakit menyediakan tempat istirahat untuk sementara waktu dalam proses isolasi mandiri. Kedua memberikan pengetahuan terkait penyakit, langkah-langkah penggunaan alat perlindungan diri dan melakukan pelatihan sebelum menangani pasien COVID-19. Ketiga rumah sakit mengembangkan protokol kesehatan secara rinci terkait pengelolaan peralatan pelindungan diri selama pandemik COVID-19. Keempat tentang cara bersantai dengan baik untuk mengurangi tekanan psikologis (Chen et al., 2020; Xiang et al., 2020). Hasil penelitian menunjukkan bahwa adanya intervensi psikologis yang dilakukan ada lebih dari 100 petugas kesehatan garda depan dapat beristirihat ditempat kerja yang sudah disediakan, merasa lebih tenang, nyaman dan memilik respon yang baik selama merawat pasien COVID-19 (Kang et al., 2020).

\section{SIMPULAN}

Adanya pandemik COVID-19, perawat harus memberikan pelayanan yang optimal terkait tindakan pencegahan dan pengendalian infeksi untuk keselamatan dirinya dan masyarakat. Hal tersebut menjadikan suatu tekanan psikologis yang terjadi pada perawat selama merawat pasien COVID-19. Artikel ini bertujuan untuk mendapatkan gambaran respon 
Muhamad Ridlo, Suhartini Ismail, Nana Rochana, Sarinti, Respon Psikologis Perawat Selama Pandemik COVID-19: Scoping Review

psikologis perawat selama COVID-19 dengan pendekatan scoping review. Tema yang didapatkan antara lain kecemasan, gejala depresi, perasaan takut, khawatir dan adanya stres akut. Respon psikologis yang telah dikumpulkan menjadi data informasi untuk memberikan intervensi psikologis bagi perawat untuk meningkatkan kesehatan mental atau psikologis pada petugas kesehatan garda depan selama pandemik COVID-19.

\section{DAFTAR PUSTAKA}

Aksoy, Y. E., \& Koçak, V. (2020). Psychological effects of nurses and midwives due to COVID-19 outbreak: The case of Turkey. Archives of Psychiatric Nursing, (July). https://doi.org/10.1016/j.apnu.2020.07.01 1

Arksey, H., \& O’Malley, L. (2005). Scoping studies: Towards a methodological framework. International Journal of Social Research Methodology: Theory and Practice, 8(1), 19-32. https://doi.org/10.1080/13645570320001 19616

Asmundson, G. J. G., \& Taylor, S. (2020). How health anxiety influences responses to viral outbreaks like COVID-19: What all decision-makers, health authorities, and health care professionals need to know. Journal of Anxiety Disorders, 71(March), 102211.https://doi.org/10.1016/j.janxdis.2 020.102211

Bao, Y., Sun, Y., Meng, S., Shi, J., \& Lu, L. (2020). 2019-nCoV epidemic: address mental health care to empower society. The Lancet, 395(10224), e37-e38. https://doi.org/10.1016/S01406736(20)30 309-3

Barry, M., Al Amri, M., \& Memish, Z. A. (2020). Covid-19 in the shadows of
MERS-CoV in the Kingdom of Saudi Arabia. Journal of Epidemiology and Global Health, 10(1), 1-3. https://doi.org/10.2991/jegh.k.200218.00 3

Cable News Network Indonesia. (2020). Tingginya Kematian Nakes Indonesia Akibat COVID-19. Retrieved September 10, 2020, from https://www.cnnindonesia.com/nasional/2 0200804155902-20-532096/menyoaltingginya-kematian-nakes-indonesiaakibat-covid-19

Cai, H., Tu, B., Ma, J., Chen, L., Fu, L., Jiang, Y., \& Zhuang, Q. (2020). Psychological Impact and Coping Strategies of Frontline Medical Staff in Hunan Between January and March 2020 During the Outbreak of Coronavirus Disease 2019 (COVID- 19) in Hubei, China. Medical Science Monitor: International Medical Journal of Experimental and Clinical Research, 26.

https://doi.org/10.12659/MSM.924171

Chen, Q., Liang, M., Li, Y., Guo, J., Fei, D., Wang, L., ... Zhang, Z. (2020). Mental health care for medical staff in China during the COVID-19 outbreak. The Lancet Psychiatry, 7(4), e15-e16. https://doi.org/10.1016/S22150366(20)30078-X

Elhadi, M., Msherghi, A., Elgzairi, M., Alhashimi, A., Bouhuwaish, A., Biala, M., ... Albakoush, A. (2020). Psychological status of healthcare workers during the civil war and COVID19 pandemic: A cross-sectional study. Journal of Psychosomatic Research, 137. https://doi.org/10.1016/j.jpsychores.2020. 110221

Hong, S., Ai, M., Xu, X., Wang, W., Chen, J., Zhang, Q., ... Kuang, L. (2020). Immediate Psychological Impact on Nurses working at 42 GovernmentDesignated Hospital During COVID-19 Outbreak in China: a cross-sectional study. Nursing Outlook, O(1), 1-7. 
https://doi.org/10.1016/j.outlook.2020.07. 007

Hu, D., Kong, Y., Li, W., Han, Q., Zhang, X., Zhu, L. X., ... Zhu, J. (2020). Frontline nurses' burnout, anxiety, depression, and fear statuses and their associated factors during the COVID-19 outbreak in Wuhan, China: A large-scale crosssectional study. EClinicalMedicine,24. https://doi.org/10.1016/j.eclinm.2020.100 424

International Council of Nurse. (2020). More than 600 nurses die from COVID-19 worldwide. Retrieved from https://www.icn.ch/news/more-600nurses-die-covid-19-worldwide

Jiang, X., Deng, L., Zhu, Y., Ji, H., Tao, L., Liu, L., ... Ji, W. (2020). Psychological crisis intervention during the outbreak period of new coronavirus pneumonia from experience in Shanghai. Psychiatry Research, 286(February), 112903. https://doi.org/10.1016/j.psychres.2020.1 12903

Juan, Y., Yuanyuan, C., Qiuxiang, Y., Cong, L., Xiaofeng, L., Yundong, Z., ... Yujie, L. (2020). Psychological distress surveillance and related impact analysis of hospital staff during the COVID-19 epidemic in Chongqing, China. Comprehensive Psychiatry, 152198. https://doi.org/10.1016/j.comppsych.2020 .152198

Kang, L., Li, Y., Hu, S., Chen, M., Yang, C., Yang, B. X., ... Liu, Z. (2020). The mental health of medical workers in Wuhan, China dealing with the 2019 novel coronavirus. The Lancet Psychiatry, 7(3), e14. https://doi.org/10.1016/S22150366(20)30047-X

Lai, J., Ma, S., Wang, Y., Cai, Z., Hu, J., Wei, N., ... Hu, S. (2020). Factors Associated With Mental Health Outcomes Among Health Care Workers Exposed to Coronavirus Disease 2019. JAMA Network Open, 3(3), e203976. https://doi.org/10.1001/jamanetworkopen. 2020.3976

Lau, H., Khosrawipour, V., Kocbach, P., Mikolajczyk, A., Ichii, H., Schubert, J., ... Khosrawipour, T. (2020). Internationally lost COVID-19 cases. Journal of Microbiology, Immunology and Infection, (xxxx), 1-5. https://doi.org/10.1016/j.jmii.2020.03.013

Lee, M. C. C., Thampi, S., Chan, H. P., Khoo, D., Chin, B. Z. B., Foo, D. P. X., ... Jacob, R. (2020). Psychological distress during the COVID-19 pandemic amongst anaesthesiologists and nurses. British Journal of Anaesthesia, (xxx), 1-4. https://doi.org/10.1016/j.bja.2020.07.005

Li, S. H., \& Graham, B. M. (2017). Why are women so vulnerable to anxiety, traumarelated and stress-related disorders? The potential role of sex hormones. The Lancet Psychiatry, 4(1), 73-82. https://doi.org/10.1016/S22150366(16)30358-3

Li, Z., Ge, J., Yang, M., Feng, J., Qiao, M., Jiang, R., ... Yang, C. (2020). Vicarious traumatization in the general public, members, and non-members of medical teams aiding in COVID-19 control. Brain, Behavior, and Immunity. https://doi.org/10.1016/j.bbi.2020.03.007

Liu, Q., Luo, D., Haase, J. E., Guo, Q., Wang, X. Q., Liu, S., ... Yang, B. X. (2020). The experiences of health-care providers during the COVID-19 crisis in China: a qualitative study. The Lancet Global Health, (20), 1-9. https://doi.org/10.1016/S2214-

109X(20)30204-7

Liu, Y., Zhang, J., Hennessy, D. A., \& Zhao, S. (2019). Psychological strains, depressive symptoms, and suicidal ideation among medical and non-medical staff in urban china. Journal of Affective Disorders, 245, 22-27.

https://doi.org/10.1016/j.jad.2018.10.111

Lu, W., Wang, H., Lin, Y., \& Li, L. (2020). Psychological status of medical workforce 
Muhamad Ridlo, Suhartini Ismail, Nana Rochana, Sarinti, Respon Psikologis Perawat Selama

during the COVID-19 pandemic: A crosssectional study. Psychiatry Research, 288(March), $1-5$. https://doi.org/10.1016/j.psychres.2020.11 2936

Manser, S. S., Houck, K., Kramer, M. D., Tabas, I. A., Brown, C. V. R., \& Coopwood, B. (2018). Do screening and a randomized brief intervention at a Level 1 trauma center impact acute stress reactions to prevent later development of posttraumatic stress disorder? In Journal of Trauma and Acute Care Surgery (Vol. $85)$.

https://doi.org/10.1097/TA.000000000000 1977

Moher, D., Liberati, A., Tetzlaff, J., Altman, D. G., Altman, D., Antes, G., ... Tugwell, P. (2009). Preferred reporting items for systematic reviews and meta-analyses: The PRISMA statement. PLoS Medicine, 6(7). https://doi.org/10.1371/journal.pmed.1000 097

Mohindra, R., R, R., Suri, V., Bhalla, A., \& Singh, S. M. (2020). Issues relevant to mental health promotion in frontline health care providers managing quarantined/isolated COVID19 patients. Asian Journal of Psychiatry, 51(April), 102084.

https://doi.org/10.1016/j.ajp.2020.10208

Rana, W., Mukhtar, S., \& Mukhtar, S. (2020). Mental health of medical workers in Pakistan during the pandemic COVID-19 outbreak. Asian Journal of Psychiatry.

Rossi, R., Socci, V., Pacitti, F., Lorenzo, G. Di, Marco, A. Di, Siracusano, A., \& Rossi, A. (2020). Mental Health Outcomes Among Frontline and Second-Line Health Care Workers During the Coronavirus Disease 2019 ( COVID-19 ) Pandemic in Italy. JAMA Network Open, (5), 1-4. https://doi.org/10.1001/jamanetworkopen. 2020.10185

Shechter, A., Diaz, F., Moise, N., Anstey, D. E., Ye, S., Agarwal, S., ... Abdalla, M.
(2020). Psychological distress, coping behaviors, and preferences for support among New York healthcare workers during the COVID-19 pandemic. General Hospital Psychiatry, 66(May), 1-8. https://doi.org/10.1016/j.genhosppsych.20 20.06.007

Shen, X., Zou, X., Zhong, X., Yan, J., \& Li, L. (2020). Psychological stress of ICU nurses in the time of COVID-19. Critical Care, 2-4. https://doi.org/10.1186/s13054-02002926-2

Sun, N., Wei, L., Shi, S., Jiao, D., Song, R., Ma, L., ... Wang, H. (2020). A qualitative study on the psychological experience of caregivers of COVID-19 patients. American Journal of Infection Control, 000, 3-9. https://doi.org/10.1016/j.ajic.2020.03.018

Tan, B. Y. Q., Chew, N. W. S., Lee, G. K. H., Jing, M., Goh, Y., Yeo, L. L. L., ... Sharma, V. K. (2020). Psychological Impact of the COVID-19 Pandemic on Health Care Workers in Singapore. Annals of Internal Medicine, 173(4), 317-320. https://doi.org/10.7326/M20-1083

Temsah, M. H., Al-Sohime, F., Alamro, N., AlEyadhy, A., Al-Hasan, K., Jamal, A., ... Somily, A. M. (2020). The psychological impact of COVID-19 pandemic on health care workers in a MERS-CoV endemic country. Journal of Infection and Public Health, 13(6), 877-882. https://doi.org/10.1016/j.jiph.2020.05.02

Wang, C., Pan, R., Wan, X., Tan, Y., Xu, L., Ho, C. S., \& Ho, R. C. (2020). Immediate Psychological Responses and Associated Factors during the Initial Stage of the 2019 Coronavirus Disease (COVID-19) Epidemic among the General Population in China. Internationl Journal of Environmental Research and Public Health. https://doi.org/10.3390/ijerph17051729

Wang, H., Huang, D., Huang, H., Zhang, J., Guo, L., Liu, Y., ... Geng, Q. (2020). The psychological impact of the COVID-19 
pandemic on medical students in Turkey. Pakistan Journal of Medical Sciences, 36(6), 1355-1359. https://doi.org/10.12669/pjms.36.6.2985

World Health Organization. (2020). Coronavirus Disease 2019 (COVID-19). https://doi.org/10.1097/jcn.000000000000 0710

Xiang, Y. T., Yang, Y., Li, W., Zhang, L., Zhang, Q., Cheung, T., \& Ng, C. H. (2020). Timely mental health care for the 2019 novel coronavirus outbreak is urgently needed. The Lancet Psychiatry, 7(3), 228-229. https://doi.org/10.1016/S22150366(20)30046-8

Xiao, C. (2020). A novel approach of consultation on 2019 novel coronavirus (COVID-19)-related psychological and mental problems: Structured letter therapy. Psychiatry Investigation, 17(2), 175-176. https://doi.org/10.30773/pi.2020.0047 